\title{
Perception, Prevalence and Predictors of Rape among Female Students in a Tertiary Institution South East Nigeria
}

\author{
Prosper O. U. Adogu',2*, Echendu D. Adinma1, Victor I. Onyiaorah³, Chika F. Ubajaka1 \\ ${ }^{1}$ Department of Community Medicine, NAU/NAUTH, Nnewi, Nigeria \\ ${ }^{2} \mathrm{PHC}, \mathrm{NAU} / \mathrm{NAUTH}, \mathrm{Nnewi}$, Nigeria \\ ${ }^{3}$ Department of Histopathology, NAU/NAUTH, Nnewi, Nigeria \\ Email: " prosuperhealth@yahoo.com
}

Received 28 May 2014; revised 23 June 2014; accepted 15 July 2014

Copyright (C) 2014 by authors and Scientific Research Publishing Inc.

This work is licensed under the Creative Commons Attribution International License (CC BY). http://creativecommons.org/licenses/by/4.0/

(c) (7) Open Access

\section{Abstract}

The essential elements of the rape crime are sexual penetration, force, and the lack of consent. The prevalence of rape worldwide has been reported to be a staggering $20 \%$. In Nigeria, most victims of rape will elect to remain silent about the experience, because of stigmatization leading to under reporting of the crime. This study was aimed at elucidating the perception of rape and determining its prevalence and predictors among female undergraduates in a tertiary institution in South Eastern Nigeria. This was a descriptive cross sectional study in which self administered questionnaires were used to collect relevant data from $\mathbf{2 8 0}$ female undergraduates of UNIZIK Okofia Nnewi Campus, Nigeria, selected by cluster sampling technique. Data were analyzed using Statistical Package for Social Sciences (SPSS) version 19. Bivariate and multivariate analyses were used to determine associations and identify independent predictors of rape respectively. The level of significance was set at $p<0.05$. Result showed that the female students had a good knowledge and the perception of rape and that some had fallen victims $(16.4 \%)$. Acquaintance rape was markedly common $(p<0.02)$. The single $(p<0.032)$, and off campus $(p<0.031)$ female students, often the party going $(p<0.02)$ types who enjoyed night $(p<0.029)$ activities were significantly more likely to become victims of rape than those married, on campus and non-party-going counterparts. Also, students who attended single gender schools $(p<0.03)$ were more predisposed to rape than those counterparts who attended co-educational colleges. Awareness campaigns through peer education, introduction of sexuality education in the school curriculum and establishment of school health programmes are highly recommended.

${ }^{*}$ Corresponding author.

How to cite this paper: Adogu, P.O.U., Adinma, E.D., Onyiaorah, V.I. and Ubajaka, C.F. (2014) Perception, Prevalence and Predictors of Rape among Female Students in a Tertiary Institution South East Nigeria. International Journal of Clinical Medicine, 5, 819-828. http://dx.doi.org/10.4236/ijcm.2014.514110 


\section{Keywords}

\section{Perception, Prevalence, Predictors, Rape, Female, Tertiary Institution, Nigeria}

\section{Introduction}

"Rape" is defined from a legal standpoint as the forcible penetration by a penis or object where there is no consent [1]. However, it is important to recognize that there are variations in the definition of rape from country to country largely around what constitutes "force" and "consent" [1]. The essential elements of the crime were sexual penetration, force, and the lack of consent [1]. Women who were raped were expected to have physically resisted to the utmost of their powers or their assailant would not be convicted of rape [2]. Some forms of sexual violence include unwanted sexual touching, forced sexual contact or activities other than sexual intercourse, and unwanted exposure to sexual activities as a forced participant or observer. It is not being suggested here that only forcible penetration is "real rape", or the only form of real and devastating sexual violence [2].

Lifetime prevalence of rape and attempted rape worldwide has been reported to be a staggering $20 \%$, while gender-based violence in general against women affects over 30\% [3] [4]. A recent national household survey, the National Intimate Partner and Sexual Violence Survey (NISVS) in the USA, reported 12.3\% of American women 18 years and older had experienced a completed forced rape in their lifetime [5]. This translates to 14.6 million women who are living with the consequences of rape. These latest study findings are consistent with previous findings from four national household surveys spanning a period of 15 years that showed between 1 in $6(16 \%)$ and 1 in 8 (13\%) women were raped in their lifetime [6]. Together, these five studies provide strong indication of the stability of rape prevalence over time.

Approximately 620,000 women 18 years and older were forcibly raped in 2010 [5]. This number is an underestimate of the total number of females sexually assaulted and raped each year for a number of reasons. Among them is the lack of inclusion of many women at high risk of sexual assault who have no access to telephones, such as women who are homeless, in hospitals, nursing homes or mental health institutions or other controlled environments like jail or residential treatment. Additionally the survey did not include girls under the age of 18 . Furthermore, in developing countries such as Nigeria, for reasons of stigma and fear of rejection, many cases of rape happen unreported by the victims and their families.

Most frequent rapes are committed by acquaintances of the victim. Rapes by a stranger account for between $11 \%$ - 18\% of rapes, with the most recent national study — the NISVS [7] — finding that $13.8 \%$ of rapes and sexual assaults were committed by strangers to the victim. Only between $16 \%$ and $19 \%$ of rapes are reported to the police [8]. Two to eight percent of police reports of rape are proven false [9]. However other studies have found that rape assailant usually ranges from a person close to the victim like a relative, neighbour, friend, school mate, teacher, caregiver, husband or guardian to a stranger [10]. It has been found that women are more likely to be raped by someone they know than by someone they do not know [11] [12]. Adolescents and young adults are four times more likely to be victims of sexual assault than women in all other age groups [13]. In the vast majority of these cases, the perpetrator is an acquaintance of the victim. Date rape is a subset of acquaintance rape where nonconsensual sex occurs between two people who are in a romantic relationship [13].

Nigeria is a traditional and culture bound non-permissive society in which studies have shown that female sexual assault is prevalent. However, only 10 - 50 percent of female victims report sexual assault [14]. Most victims of rape in this country will elect to remain silent about the experience, because of stigmatization [15]. Consequently, under-reporting of cases of rape is mainly due to social stigma, prejudice with regard to chances of marriage, fear of being considered promiscuous and responsible for incidence, attendant humiliation and shame. Moreover, there is the embarrassment caused by appearance and cross examination in court, publicity in press, risk of losing the love and respect of society, friends and that of husband, if married [16]. Roughly two-thirds of sexual assaults occur under the cover of darkness. Most of the sexual assaults occur in the residence of the victim, the assailant or other individuals; other prevalent locations are street, commercial building, and inside a school building or property [17]. This study was aimed at eliciting the perception of rape and determining its prevalence and predictors among female students in Okofia, Nnewi Campus of Nnamdi Azikiwe University, Nigeria. 


\section{Methods}

This was a descriptive cross-sectional study which used self administered questionnaires for data collection among female undergraduate students at the Okofia, Nnewi Campus of the Nnamdi Azikiwe University. The study population was undergraduate, female students and the setting was at the faculties of Basic Medical Sciences and Health Sciences \& Technology, all in Okofia, Nnewi Campus of the Nnamdi Azikiwe University, Nigeria.

From a population size of about 1000, the sample size was calculated using the appropriate formula [18] for populations less than 10,000, with an assumed frequency of 50\%, a standard normal deviate of 1.96 and a desired accuracy at 0.05 , which yielded the minimum sample size of $(n)=277$. To compensate for non-response and attrition, the sample size was further increased to $n=308$ based on anticipated response rate of $90 \%$. Cluster sampling technique was applied using probability proportion to size applied to year of study. With a sampling frame of 1000, a sample size of 308 was arrived at and proportionately distributed among the 200, 300 and 400 levels students in the ratio of 2:3:4. This resulted in samples sizes of 68, 108 and 136 respectively.

The second, third and fourth authors closely supervised data collection from the female students in the lecture halls at the end of class sessions in the departments of nursing science, second year medical students, physiotherapy, anatomy, medical laboratory science and human physiology. Data were collected using self administered, mixed open and close-ended questionnaires. Three hundred and eight such instruments were handed out; 280 were returned; yielding a response rate of approximately 90.9\%. Socio-demographic characteristics are the predictor variables while the singular outcome variable in this study was rape.

Data were analyzed using Statistical Package for Social Sciences (SPSS) version 19. Quantitative variables were summarized using appropriate measures of location and variability. Categorical variables were presented as frequencies and percentages. Bivariate analysis by use of the Chi-square test and standard error of difference between percentages were employed to assess the significance of associations between rape and socio-demographic variables. Crude odds ratios (OR) were obtained while multivariate logistic regression was used to compute adjusted ORs and to identify independent predictors of rape. The level of significance was set at $\mathrm{p}<$ 0.05 .

\section{Results}

A total of $n=280$ female undergraduate students participated in this cross-sectional study. The mean age was $22.2 \pm 5.11$ years ( $\mathrm{SD}=5.11$ ) and ranged from 17 years to 37 years. Just over $40 \%$ of the respondents were below the age of 20 years age category. Two hundred and thirty (82.1\%) were single while 17.9 were married. The 400 level class constituted $42.1 \%$ of the respondents and $78.6 \%$ of them spent their adolescent life in the urban areas. Moreover, $51.6 \%$ of the subjects attended co-educational school, while the rest attended one gender school (Table 1).

Table 2 shows that majority (51.1\%) of the subjects attained menarche at age 13 - 15 years while $31.8 \%$ attained menarche after the age of 15 years. About $67.5 \%$ of the respondents agreed they have been sexually exposed even though 33.9\% experienced in first sexual intercourse after age 20 years. One hundred and ninety (72.8\%) currently (at time of study) had no sexual partner while $4 \%$ and $23.2 \%$ agreed they had two and one sexual partners respectively.

Figure 1 depicts that majority, 80 of the students perceive rape as sexual intercourse following threat to life (SFTTL), 79 perceive it as penile penetration without consent (PPWC), 56 see it as forced smooching (FS), 43 as touching one's breast without consent (TBWC) and another 43 perceived it as sexual intercourse for fear of losing privileges (SFFOLP). Twenty five students said they have no idea what rape is all about.

In Table 3, a statistically significant relationship exists between the outcome variable "rape" and predictor variables namely; marital status ( $p<0.01)$, level of study $(p<0.05)$, type of secondary school attended ( $<<$ $0.005)$, place of residence in school $(p<0.005)$ and time of rape $(p=0.05)$. Also the highest proportion $(8.6 \%)$ of rape occurred in parties, while the most common assailant of the rape victim was the boy/family friend.

Table 4 presents the specific predictors of rape among the group variables that are significantly associated with rape as earlier shown in Table 3 . The 300 level female students were significantly more likely to fall victim of rape than the other level students [AOR $1.65(\mathrm{p}<0.042)$ ]. Also the single female students were significantly more likely to be raped than their married counterparts [AOR 1.77 ( $p<0.032$ )]. Furthermore, the female students who lived off-campus have significantly greater odds of becoming rape victims than the on-campus students 
Table 1. Socio-demographic characteristics of respondents.

\begin{tabular}{lcc}
\hline \multicolumn{1}{c}{ Characteristics } & Number & Percent (\%) \\
\hline Age (years) & 113 & 40.4 \\
$<20$ & 88 & 31.4 \\
$20-24$ & 52 & 18.6 \\
$25-29$ & 23 & 8.2 \\
$30-34$ & 4 & 1.4 \\
$>34$ & 280 & 100 \\
Total & $22.2 \pm 5.11$ & \\
Mean \pm SD & & \\
Marital status & 50 & 17.9 \\
Married & 230 & 82.1 \\
Single & 280 & 100 \\
Total & & \\
Level (year of study) & 55 & 19.6 \\
200 (year 2) & 107 & 38.2 \\
300 (year 3) & 118 & 42.1 \\
400 (year 4) & 280 & 100 \\
Total & & \\
Town where respondent spent adolescent life & 220 & 78.6 \\
Urban & 60 & 21.4 \\
Semi-urban/rural & 280 & 100 \\
Total & & \\
Type of secondary school & 144 & 51.4 \\
Co-educational & 280 & 48.6 \\
One gender school & & \\
Total & & \\
\hline
\end{tabular}

Table 2. Sexual history of respondents.

\begin{tabular}{lcc}
\hline & Frequency & Percent (\%) \\
\hline Age at menarche (years) & 5 & 1.8 \\
$<10$ & 43 & 15.4 \\
$10-12$ & 143 & 51.1 \\
$13-15$ & 89 & 31.8 \\
$>15$ & 280 & 100 \\
Total & & \\
Sexually exposed & 189 & 67.5 \\
Yes & 91 & 32.5 \\
No & 280 & 100 \\
Total & & \\
Age at first intercourse (years) & 2 & 0.71 \\
$<10$ & 30 & 10.7 \\
$10-15$ & 62 & 22.1 \\
$16-20$ & 95 & 33.9 \\
$>20$ & 91 & 32.5 \\
Never sexually exposed & 280 & 100 \\
Total & & \\
Number of sexual partners (at time of interview) & 190 & 72.8 \\
Zero & 85 & 23.2 \\
One & 5 & 4 \\
Two & 280 & 100 \\
Total & &
\end{tabular}


Table 3. Prevalence of rape by socio demographic characteristics.

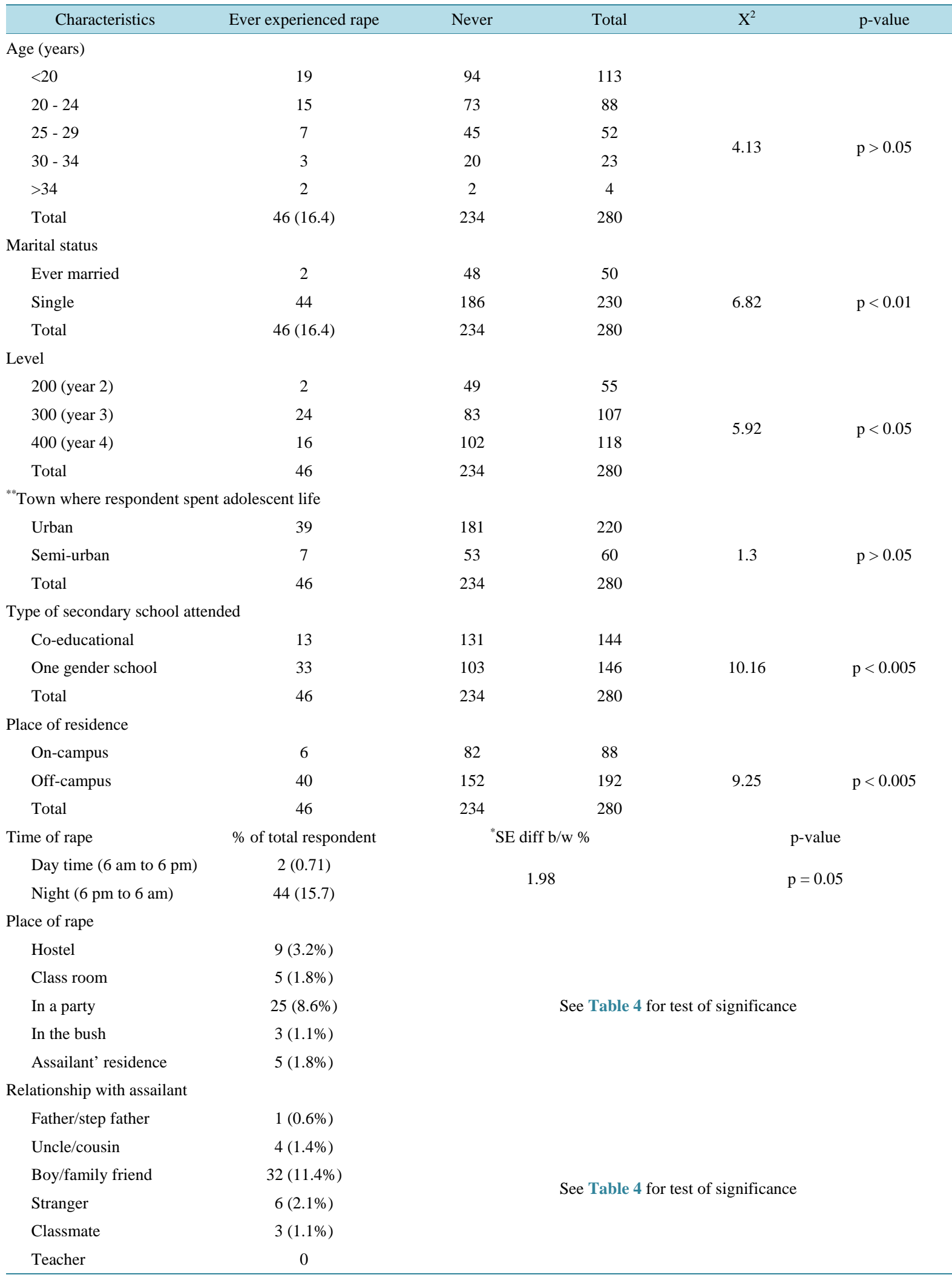

NB: ** Urban: Onitsha, Abuja, Lagos, Owerri, Jos, Aba. Semi-urban: Nnewi, Abakaliki; "Standard error of difference between percentages. 
Table 4. Predictors of rape among the subjects.

\begin{tabular}{|c|c|c|c|}
\hline Characteristics & Crude OR & Adjusted OR (95\% CI) & p-value \\
\hline \multicolumn{4}{|l|}{ Level } \\
\hline${ }^{*} 200$ & 1.2 & & \\
\hline 300 & 2.15 & $1.65(0.98-3.47)$ & 0.0042 \\
\hline 400 & 1.85 & $0.71(0.32-3.82)$ & 0.071 \\
\hline \multicolumn{4}{|l|}{ Marital status } \\
\hline "Ever married & 1.27 & & \\
\hline Single & 1.98 & $1.77(1.12-4.11)$ & 0.032 \\
\hline \multicolumn{4}{|l|}{ Place of residence } \\
\hline "On-campus & 1.43 & & \\
\hline Off campus & 2.34 & $1.92(0.93-3.78)$ & 0.031 \\
\hline \multicolumn{4}{|l|}{ Type of secondary school } \\
\hline${ }^{*}$ Co-educational school & 1.37 & & \\
\hline One gender school & 2.87 & $2.13(1.12-4.24)$ & 0.03 \\
\hline \multicolumn{4}{|l|}{ Time of rape } \\
\hline Day: 6 am to $6 \mathrm{pm}^{*}$ & 1.41 & & \\
\hline Night: 6 pm to 6 pm & 2.95 & $2.07(1.33-3.85)$ & 0.029 \\
\hline \multicolumn{4}{|l|}{ Place of rape } \\
\hline Hostel & 1.28 & $0.99(0.45-2.67)$ & 0.25 \\
\hline Class room & 1.21 & $0.85(0.33-2.90)$ & 0.46 \\
\hline In a party & 2.91 & $2.11(1.10-3.21)$ & 0.02 \\
\hline Assailant' residence & 1.39 & $0.78(0.27-2.39)$ & 0.34 \\
\hline "In the bush & 1.15 & & \\
\hline \multicolumn{4}{|l|}{ Relationship with assailant } \\
\hline Father/step father & 1.12 & $0.95(0.32-2.83)$ & 0.57 \\
\hline Uncle/cousin & 1.98 & $1.38(0.41-2.77)$ & 0.06 \\
\hline Boy/family friend & 2.73 & $2.33(1.29-3.81)$ & 0.02 \\
\hline Stranger & 1.45 & $1.19(0.26-2.61)$ & 0.31 \\
\hline Classmate & 1.23 & $1.01(0.51-2.92)$ & 0.42 \\
\hline *Teacher & 0 & & \\
\hline
\end{tabular}

${ }^{*}$ Reference category.

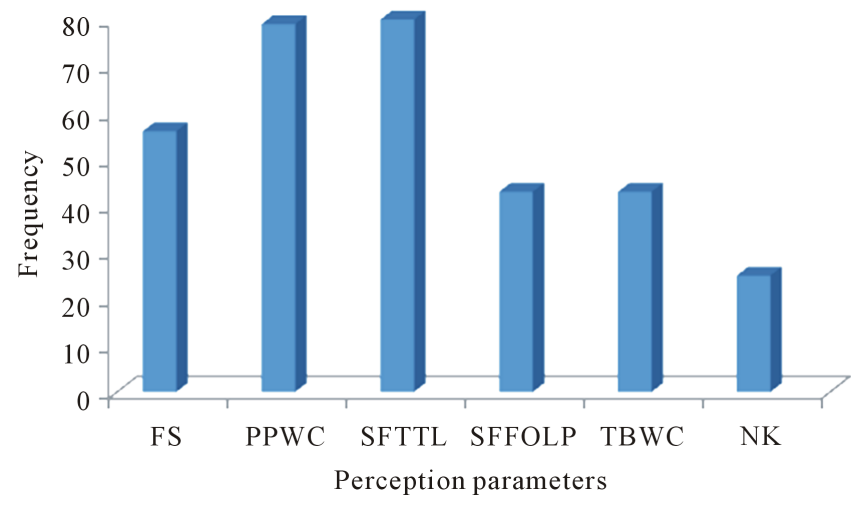

Figure 1. Perception of what constitutes rape among subjects. Key: FS: forceful smooching; PPWC: penile penetration without consent; SFTTL: sexual intercourse following threat to life; SFFOLP: sexual intercourse for fear of losing privileges; TBWC: touching one's breast without consent; NK: no knowledge. 
[AOR $1.92(\mathrm{p}<0.031)$ ], in the same manner that products of one gender schools markedly fall victims of rape compared to their co-educational school counterparts [AOR $2.13(\mathrm{p}<0.030)$ ]. Moreover rapes are significantly more likely to happen under the cover of darkness than during daylight [AOR 2.07 ( $\mathrm{p}<0.029)$ ], in the same way that the odds of rape are highest than at any other place [AOR $2.11(\mathrm{p}<0.02)$ ]. Finally the likelihood that the assailant of the rape victim is a close male friend is significantly higher [AOR $2.33(\mathrm{p}<0.02)$ ], than any other relationship situation.

\section{Discussion}

The respondents' perceptions of rape in this study are principally that of penile penetration without consent and sexual intercourse following threat to life and these are in consonance with the globally accepted legal definition of rape which revolves around what constitutes "force" and "consent" [1]. The accurate knowledge and perception of rape among the respondents could arise from their high level of academic exposure and health related field of specialization which they are all aspiring to achieve.

In this study, $16.4 \%$ of respondents agreed that they have been raped. This prevalence is much higher than 5.1\% [19] found among secondary school students in some states in North Eastern Nigeria, 4\% [20] among female apprentice tailors and 6\% in young hawkers [21] in some cities in South Western Nigeria. However, the rape prevalence in this study is comparably similar to that reported by Shittu et al. who found that 1 in every 5 sexually active teenagers had experienced forced sex among secondary school students in Oworonshoki, Lagos [22]. The apparently high prevalence of rape among the respondents in this study could be attributed partly to the isolated location of their campus in the outskirts of the main city of Nnewi. The campus is surrounded by thick bushes and coupled with the usual epileptic power supply; this presents conducive environment for rape to take place.

In this study, close acquaintances accounted for $62.5 \%$ of perpetrators of rape while $37.5 \%$ of the victims were raped by unknown persons. This finding is generally consistent with results of several other studies [23] [24] which expressed that majority of the victims were more likely to be raped by the man they know than by the man they do not know. When a female develops close familiarity with a male acquaintance she tends to build some measure of trust in him thereby relaxing her natural defenses while in his company and this makes her vulnerable to sexual attack by the trusted acquaintance.

This study has shown that the higher the class levels of the students, the greater the chance of becoming a victim of rape. The interpretation of this finding is perhaps that the longer the number of years in school, the greater the confidence built by the student to voice out any case of rape perpetrated against her. On the other hand, the apparently low incidence of rape among the fresh students must be interpreted with caution since the actual incidence of rape is assumed to be much higher than the reported figures as the crime most of the time go unreported [22] [23]. It is possible that some of these students who have been raped may not divulge the information for fear of stigmatization. Moreover the fresh student respondents may not know that having sexual intercourse with a male without their consent is rape, some may have been victims without realizing they were raped. The prevalence of rape among the respondents did not differ significantly along age lines even though it can be observed that the younger the students, the higher the prevalence of rape among them. This finding was however not statistically significant.

For the students who live off campus, the security network prevalent outside the school may not be as effective as may be found on campus, where a combination of well organized security network by students, hostel owners and the university authority may be enough to discourage a potential rapist. Also the fact that most rapes occur under the cover of darkness highlights the importance of twenty-four hour vigilante activities in curbing the incidence of the menace among female undergraduates.

The finding that the students who attended one gender secondary schools are more likely to be raped than those who attended co-educational schools is difficult to explain. However, research has shown that $84 \%$ of students attending independent co-ed schools generally feel confident expressing their views in the presence of members of the opposite sex [25] [26]. Collaboration between the sexes in the classroom helps develop confidence in students so that they feel comfortable sharing their ideas and opinions in any life situation, and excel at university [25] [26]. This means that such female student often has a good enough understanding of the male that will enable her avoid situations that can lead to rape.

This study has shown that party venues are fertile grounds for conceptualization and execution of rapes 
against the female undergraduates. This is hardly surprising since such get-togethers usually happen under the cover of darkness and off campus too. These two factors have earlier been identified in this study as strong predictors of rape among the students. Therefore they can act synergistically with the alcohol, cigarette and drugs often consumed at parties to increase the chance that rape will occur.

From the findings of this study, single students are more likely to be raped, and are more vulnerable to such attacks than their married counterparts. Marriage confers respect, dignity and responsibility on the married student who is thus not expected to embark on wild parties, drunkenness and drug abuse. She is also expected to dress responsibly according to her marital status, not in skimpy dresses as is often the case with some single students. It is often said that one is addressed as he or she is dressed. This may be true even for some cases of rape among unmarried students. Further studies are however recommended to elucidate the effect of dress code on the prevalence of rape among female undergraduates. The male students should also be incorporated in the study to examine the issue from their own point of view.

\section{Conclusion}

In conclusion, this study has shown that the female students have an accurate knowledge and the perception of what rape is and that some have fallen victims. The prevalence of rape is high among them and acquaintance rape is quite common. The single, off campus and female students, often the party loving types who enjoy night activities are more likely to fall victims of rape than those married, on campus and reserved counterparts. Moreover, the students who attend single gender schools are more likely to fall victims of rape than those counterparts who attend co-educational colleges.

\section{Recommendations}

There is need for awareness/enlightenment campaigns about rape with emphasis on prevention targeted at the students beginning from their primary school days. Peer educators should be raised and encouraged to reach their fellow students anywhere and whenever the topic arises. Parents and teachers have pivotal roles to play in disseminating the right sexuality information to the girl child. The introduction of sexuality education in the school curriculum and establishment of school health programmes are also of paramount importance. Students must be encouraged to live on campus and to avoid night activities.

There should be separation of female students from males' hostels especially during the evening, provision of Reproductive Health Education especially HIV/AIDS Education, provision of Guidance and Counseling to both victims and perpetrators of acquaintance rape, strict enforcement of institutional rules and regulations, formation of social clubs and lecturers to get in-service education on the subject of rape.

\section{Acknowledgements}

This report is part of a supervised project carried out by final year medical students in partial fulfillment of the requirements for the award of the bachelor of Medicine, Bachelor of surgery (MBBS) degree.

\section{Limitations of Study}

In this part of the world, rape is often associated with stigma, shrouded in secrecy and its discussion demands utmost confidentiality. Therefore the information volunteered (if not entirely concealed) by respondents may not be very accurate. Consequently, the researchers, in the absence of any means of verification are compelled to work with the available data.

\section{Ethical Consideration}

The purpose of the research was explained to the female students and their consent obtained before distribution of questionnaires. They were assured of confidentiality on all information given. NAUTH Institutional ethical clearance was also obtained before the study was conducted.

\section{Conflict of Interests}

No conflict of interests declared by the authors. 


\section{Funding}

The article was funded by the researchers themselves.

\section{References}

[1] (2011) The Prevalence of Rape in the United States—Illinois Coalition. http://www.icasa.org/docs/misc

[2] Tracy, C.E. and Fromson, T.L. (2012) Women's Law Project Jennifer Gentile Long, Charlene Whitman Rape and Sexual Assault in the Legal System-Women’s Law Project. Rape and Sexual Assault in the Legal System Presented to the National Research Council of the National Academies Panel on Measuring Rape and Sexual Assault in the Bureau of Justice Statistics Household Surveys Committee on National Statistics. http://www.womenslawproject.org/NewPages/hrHelpful_Resources.html

[3] MacDonald, R. (2000) Time to Talk about Rape. BMJ, 321, 1034-1035. http://dx.doi.org/10.1136/bmj.321.7268.1034

[4] United Nations Population Fund (UNFPA) (2004) State of World Population 2004. UNFPA, New York, 31.

[5] Black, M., Basile, K., Breiding, M., Smith, S., Walters, M., Merrick, M., Chen, J. and Stevens, M. (2011) The National Intimate Partner and Sexual Violence Survey (NISVS): 2010 Summary Report. National Center for Injury Prevention and Control, Centers for Disease Control and Prevention, Atlanta.

[6] Basile, K., Chen, J., Black, M. and Saltzman, L. (2007) Prevalence and Characteristics of Sexual Violence Victimization among U.S. Adults, 2001-2003. Violence and Victims, 22, 437-448. http://dx.doi.org/10.1891/088667007781553955

[7] Tjaden, P. and Thoennes, N. (2000) Full Report of the Prevalence, Incidence, and Consequences of Violence against Women. U.S. Department of Justice, Washington DC.

[8] Kilpatrick, D., Edmunds, C. and Seymour, A. (1992) Rape in America: A Report to the Nation. National Victim Center, Arlington.

[9] Lonsway, K., Archambault, J. and Lisak, D. (2009) False Reports: Moving the Issue to Successfully Investigate and Prosecute Non-Stranger Sexual Assault. The Voice, 3, 1. www.ndaa.org/ncpvaw the_voice_newsletter.html

[10] Kilpatrick, D., Resnick, H., Ruggiero, K., Conoscenti, L. and McCaluley, J. (2007) Drug-Facilitated, Incapacitated, and Forcible Rape: A National Study. U.S. Department of Justice, Washington DC.

[11] Petter, L.M. and Whitehill, D.L. (1998) Management of Female Sexual Assault. American Family Physician, 58, 929.

[12] Dunn, S.F. and Gilchrist, V.J. (1993) Sexual Assault. Prim Care, 20, 359-373.

[13] Rickert, V.I. and Wiemann, C.M. (1998) Date Rape among Adolescents and Young Adults. Journal of Pediatric and Adolescent Gynecology, 11, 167-175. http://dx.doi.org/10.1016/S1083-3188(98)70137-8

[14] Malhotra, N. and Sood, M. (2000) Sexual Assault, a Neglected Public Health Problem in Developed World. International Journal of Gynecology \& Obstetrics, 71, 257-258. http://dx.doi.org/10.1016/S0020-7292(00)00276-9

[15] Green, T., Adriana, R. and Mavis, M. (2001) Patterns among Sexual Assault Victims Seeking Treatment Services. Journal of Child Sexual Abuse, 10, 89-108. http://dx.doi.org/10.1300/J070v10n01_05

[16] Beebe, D.K. (1991) Emergency Management of the Adult Female Rape Victim. American Family Physician, 43, 20412046.

[17] Greenfield, L. (1997) Sex Offences and Assailants. An Analysis of Data on Rape and Sexual Assault. BJS Report, NCJ 163392.

[18] Araoye, M.O. (2003) Research Methodology with Statistics for Health and Social Sciences. Nathadex Publishers, Ilorin, 119-120.

[19] Ajuwon, A.J., Olaleye, A., Faromoju, B. and Ladipo, O. (2006) Sexual Behaviour and Experience of Sexual Coercion among Secondary School Students in Three States in North Eastern Nigeria. BMC Public Health, 6, 310. http://dx.doi.org/10.1186/1471-2458-6-310

[20] Ajuwon, A.J., McFarland, W., Hudes, S., Adedapo, S., Okikiolu, T. and Lurie, P. (2002) Risk-Related Behaviour, Sexual Coercion and Implications for Prevention Strategies among Female Apprentice Tailors in Ibadan, Nigeria. AIDS and Behavior, 6, 233-241. http://dx.doi.org/10.1023/A:1019839824312

[21] Fawole, O.I., Ajuwon, A.J., Osungbade, K.O. and Faweya, O.C. (2002) Prevalence of Violence against Young Female Hawkers in Three Cities in South Western Nigeria. Health Education, 102, 230-238. http://dx.doi.org/10.1108/09654280210444100

[22] Shittu, L.A.J., Zechariah, M.P., Ajayi, G., Oguntola, J.A., Izegbu, M.C. and Ashiru, O.A. (2007) The Negative Impacts of Adolescent Sexuality Problems among Secondary School Students in Oworonshoki Lagos. Scientific Research and Essays, 2, 23-28. 
[23] Oleribe, E.O. (2002) Themes on Child Abuse. In: Oleribe, E.O., Ed., The Concept of Child Abuse. An Anti-Child Abuse Society of Africa Publication (National War College Abuja Printing Press), Abuja, 49-92.

[24] Dominquez, R.Z., Nelke, C.F. and Perry, B.D. (2002) Child Sexual Abuse. In: Levinson, D., Ed., Encyclopedia of Crime and Punishment, Vol. 1, Sage Publications, Thousand Oaks, 202-207. http://dx.doi.org/10.4135/9781412950664.n57

[25] The Benefits of the Co-Educational Environment. www.ridleycollege.com/ftpimages/180/download/download

[26] Get the Facts-Co-Education Matters SELF-ASSESSMENT OF THEIR OWN ACADEMIC. www.appleby.on.ca Ashbury College. www.ashbury.on.ca 
Scientific Research Publishing (SCIRP) is one of the largest Open Access journal publishers. It is currently publishing more than 200 open access, online, peer-reviewed journals covering a wide range of academic disciplines. SCIRP serves the worldwide academic communities and contributes to the progress and application of science with its publication.

Other selected journals from SCIRP are listed as below. Submit your manuscript to us via either submit@scirp.org or Online Submission Portal.
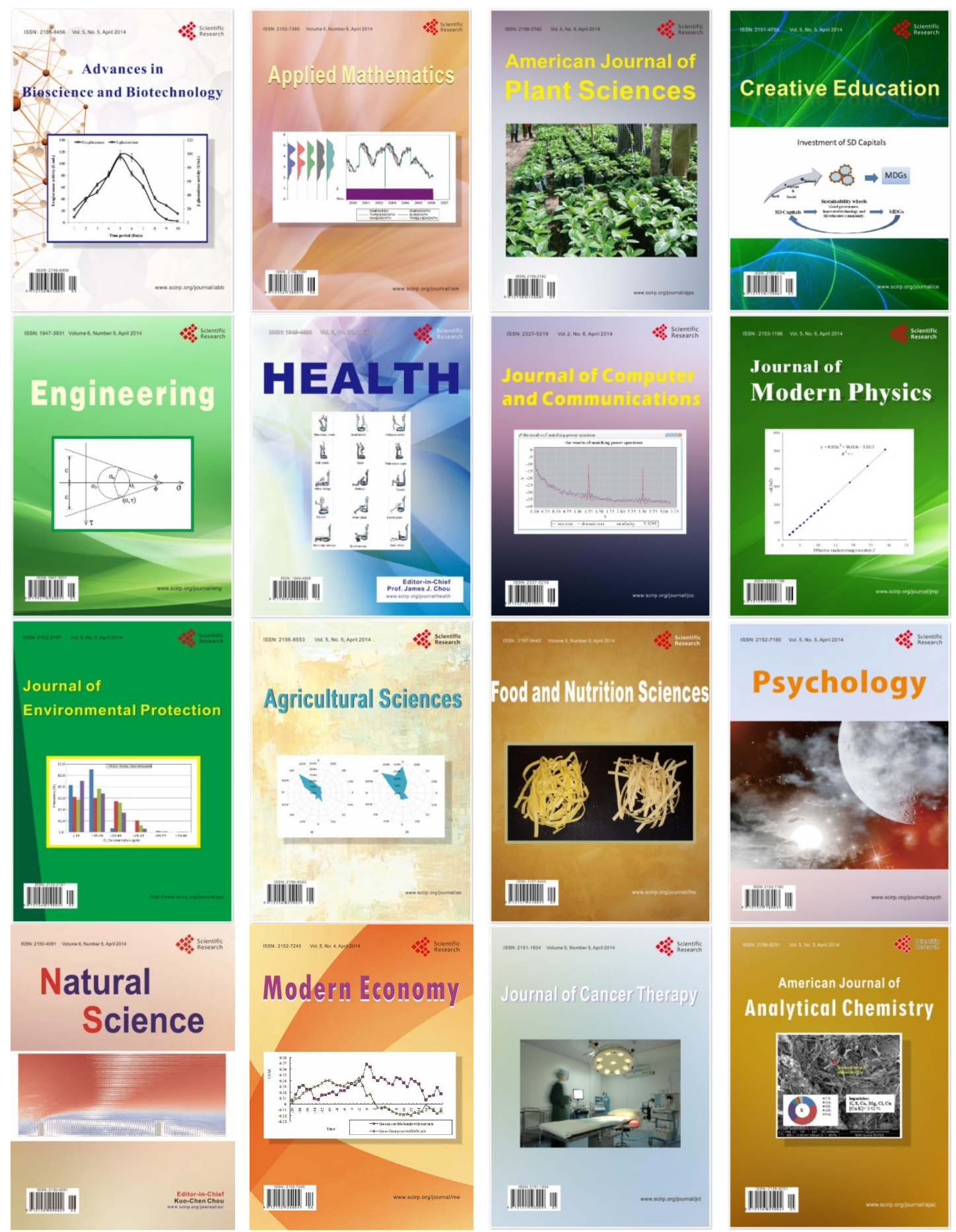